\title{
Tekirdağ Ekolojik Koșullarında Anadolu Adaçayı (Salvia fruticosa Mill.) Popülasyonlarının Verim ve Kalite Özelliklerinin Belirlenmesi
}

\author{
*Ünal KARIK', Ayșe Canan SAĞLAM² \\ ${ }^{1}$ Ege Tarımsal Araștırma Enstitüsü, Menemen, İzmir \\ ${ }^{2}$ Namık Kemal Üniversitesi Ziraat Fakültesi Tarla Bitkileri Bölümü, Tekirdağ \\ *Sorumlu yazar e-posta (Corresponding author; e-mail): unalkarik@gmail.com \\ Geliș Tarihi (Received): 25.09.2017～Kabul Tarihi (Accepted): 17.11.2017
}

\section{Öz}

Bu çalıșmada Marmara Bölgesi Florası'nda bulunan Anadolu adaçayı (Salvia fruticosa Mill.) popülasyonlarının verim ve kalite özelliklerini belirlemek amaçlanmıștır. Floradan toplanan 10 adet Anadolu adaçayı (S. fruticosa Mill.) popülasyonuna ait tohumlar, çalıșmada materyal olarak kullanılmıștır. Araștırmada, popülasyonların yeșil herba verimi (kg/da), kuru herba verimi $(\mathrm{kg} / \mathrm{da})$, yeșil yaprak verimi (kg/da), kuru yaprak verimi (kg/da), uçucu yağ oranı (\%), ve uçucu yağ bileșenleri (\%) saptanmıștır. Çalıșmada ilk yıl kuru yaprak verimi ve uçucu yağ oranı, sırası ile 439.86-691.62 kg/da ve \%3.26-4.34 arasında, ikinci yıl 507.74-986.70 kg/da ve \%2.53-3.88 arasında gerçekleșmiștir. Uçucu yağın ana bileșenleri 1.8-cineole, camphor ve $\beta$-caryophyllene olarak belirlenmiștir. Yıllara ve popülasyonlara göre 1.8-cineole oranı \%23.2-37.3, camphor oranı \%8.1-29.1 ve $\beta$-caryophyllene oranı \%2.8-14.8 arasında değișim göstermiștir.

Anahtar Kelimeler: Marmara Bölgesi, Anadolu adaçayı, Salvia fruticosa Mill., verim, kalite

\section{Determination of the Yield and Quality Characteristics of Anatolian Sage (Salvia fruticosa Mill.) Populations in Tekirdağ Ecological Conditions}

\section{Abstract}

The aim of this study was to determine the yield and quality characteristics of Anatolian sage (Salvia fruticosa Mill.) populations located in the flora of Marmara Region. Seed samples of Anatolian sage (S. fruticosa Mill.) belong to 10 populations were collected from flora composed the research material. Fresh herb yield $(\mathrm{kg} / \mathrm{da})$, dry herb yield $(\mathrm{kg} / \mathrm{da})$, fresh foliage yield $(\mathrm{kg} / \mathrm{da})$, dry foliage yield $(\mathrm{kg} / \mathrm{da})$, essential oil yield (\%) and essential oil components (\%) of populations were determined. First year dry foliage yield and essential oil yield ranged between $439.86-691.62 \mathrm{~kg} / \mathrm{da}$ and $3.26-4.34 \%$, and the following year they were between $507.74-986.70 \mathrm{~kg} / \mathrm{da}$ and $2.53-3.88 \%$ respectively. The main components of essential oil were identified as 1.8-cineole, camphor and $\beta$-caryophyllene. The present components ranged between $23.2-37.3 \%, 8.1-29.1 \%$ and $2.8-14.8 \%$ in the successive two years.

Keywords: Marmara Region, Anatolian sage, Salvia fruticosa Mill., yield, quality

\section{Giriș}

D ünyada, Kuzey ve Güney yarımkürenin ılıman bölgelerinde doğal yayılıș gösteren Salvia L. cinsi 1000'e yakın türü barındırmaktadır (Nakipoğlu 1993; 2002; Seçmen ve ark. 1998; Güner ve ark. 2000). Salvia L. cinsi Türkiye'de 97 tür, 4 alttür ve 8 varyeteye ait toplam 109 takson içermektedir. Bu türlerden 51 tanesi endemik olup, endemizm oranı (\%52.5) oldukça yüksektir. (Davis 1982; Nakipoğlu 1993; Seçmen ve ark. 2000; Doğan ve ark. 2008; İpek ve Gürbüz 2010; Güner ve ark. 2012; Șenkal ve ark. 2012). 


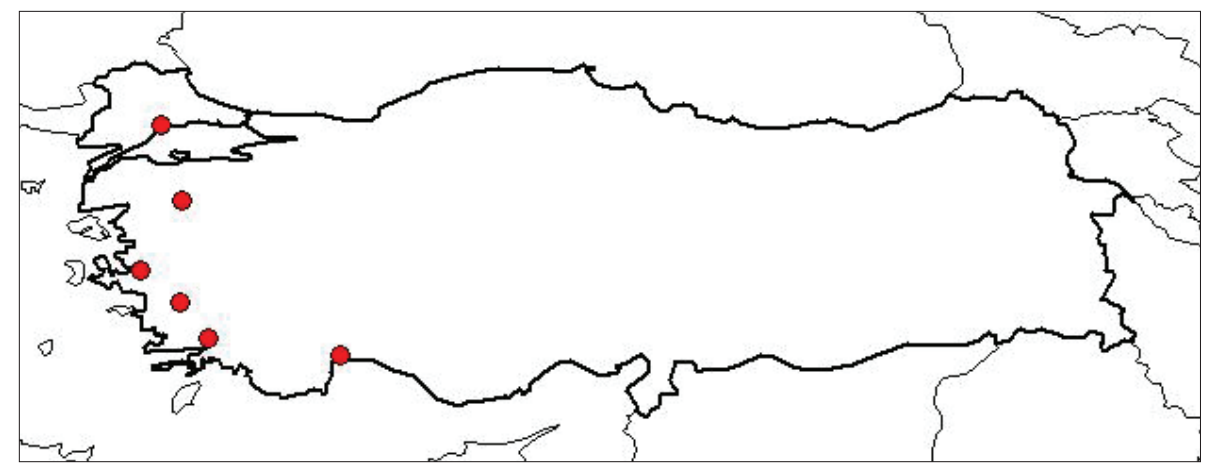

Șekil 1. Salvia fruticosa Mill.'nın Türkiye florasındaki dağılım haritası (Anonim 2012).

Figure 1. Distribution map of Salvia fruticosa Mill. in Flora of Turkey (Anonymus 2012).

Genel olarak halk hekimliğinde gaz söktürücü, yatıștırıcl, karminatif, diüretik, midevi, ter kesici, haricen yara iyileștirici ve antiseptik olarak kullanılanılan Salvia L. türleri; antibakteriyal, antifungal, antiviral, antiseptik, analjezik, antioksidan, astrenjan, antispazmodik, merkezi sinir sistemi depresanı, antisudorifik, antidiyabetik, antikanser ve insektisit aktiviteler gibi çok çeșitli biyolojik etkilere sahip bitkilerdir (Ulubelen. 1964; Rivera et al. 1994; Chalchat et al. 1998; Demirci ve ark. 2002; Lu and Leap 2002; Perry 2003; Topçu 2006).

Salvia fruticosa Mill.'nın doğal yayılma alanları Kuzey Libya, Sicilya ve Güney İtalya'dan Balkan Yarımadası'nın güney kısmına, Batı Anadolu'dan Batı Suriye'ye kadar uzanmaktadır (Pignatti 1982). Salvia fruticosa Mill. 0-800 $\mathrm{m}$ rakım arasında yayılıs gösteren Mart-Mayıs aylarında çiçeklenen, çok yıllık çalımsı bir bitkidir. Yapraklar basit veya üç loblu, çiçekleri genellikle açık eflatun nadiren beyaz, meyve rengi açık kahverenginden koyu kahverengiye kadar değișmektedir. Bin tohum ağırlığı ortalama 4 g'dır (Hedge 1982; Ceylan 1987; Baytop 1999). Șekil 1.'de Salvia fruticosa Mill.'ın ülkemizdeki yayılıș alanları görülmektedir.

Farklı araștıııılar tarafından değișik ekolojilerde yapılan çalıșmalarda; Salvia fruticosa Mill.'nın yeșil herba verimi 639-6558 $\mathrm{kg} / \mathrm{da}$, kuru herba verimi $258.1-2058.73 \mathrm{~kg} /$ da, kuru yaprak verimi $161.3 \mathrm{~kg} / \mathrm{da}$, uçucu yağ oranı \% 0.9-5.15, uçucu yağın ana bileșeni olan 1.8-cineole oranı \%15.25-80.80 arasında bulunmuștur. Türkiye'de Salvia L. türleri uçucu yağlarındaki ana bileșenlerine göre sınıflandırmıștır. Buna göre Salvia fruticosa Mill. 1.8-cineole/camphor grubunda yer almaktadır (Kalafatcılar 1996; Bayram ve ark. 1999; Bayram 2001; Bașer 2002; Bașer ve Kırımer 2006; Așkun ve ark. 2010; Mossi et al. 2011; Karık 2015).

Anadolu adaçayı (Salvia fruticosa Mill.) ülkemizin kuzeybatısından güneybatısına kadar uzanan bölgede farklı lokasyonlarda yayılıș gösteren ve ticari önemi olan bir türdür. Uzun yıllardan beri doğadan toplanarak kullanılan bu türün hem iç pazarda hem de dıș pazarda tıbbi ve aromatik bitkiler içerisinde azımsanmayacak bir yeri bulunmaktadır. Üretim ve ihracatın tamamı doğadan toplanarak karșılanmaktadır. Anadolu adaçayı (Salvia fruticosa Mill.)'nın hem doğadan așırı toplanması sonucu florada artan baskının giderilmesi, hem de standart bir üretim yapılabilmesi için mutlaka kültürel üretimine geçilmesi gerekmektedir.

Bu çalıșmada; Marmara Bölgesi doğal bitki örtüsünde yetișen Anadolu adaçayı (Salvia fruticosa Mill.) popülasyonlarının verim ve kalite özellikleri saptanmıștır. Verim ve kalite özellikleri belirlenen materyal ile ülkemizde çok fazla miktarda tüketilen ve yurt dıșına ihraç edilen bu üründe gelecekte yapılacak olan Islah ve çeșit elde etmeye yönelik çalıșmalara kaynak materyal olușturulması ve üretimine yönelik çalıșmalara katkı sağlanması amaçlanmıștır.

\section{Materyal ve Yöntem}

Araștırmada, Marmara Bölgesi doğal bitki örtüsünde bulunan Anadolu adaçayı 
Çizelge 1. Salvia fruticosa Mill. tohum toplama yapılan lokasyonlar

Table 1. Locations of collected Salvia fruticosa Mill. seed samples

\begin{tabular}{|c|c|c|}
\hline Pop No & Toplandığı Yer & Koordinatlar \\
\hline 1 & Tekirdağ-Merkez-Kumbağ & $40^{0} 51.591 \mathrm{~K} 27^{0} 27.513 \mathrm{D} 8 \mathrm{~m}$ \\
\hline 2 & Tekirdağ-Șarköy-Uçmakdere & $40^{\circ} 51.525 \mathrm{~K} 27^{\circ} 21.478 \mathrm{D} 44 \mathrm{~m}$ \\
\hline 3 & Tekirdağ-Șarköy-Gaziköy & $40^{\circ} 45.385 \mathrm{~K} 27^{\circ} 20.069 \mathrm{D} 140 \mathrm{~m}$ \\
\hline 4 & Tekirdağ-Merkez-Uçmakdere & $40^{\circ} 48.385 \mathrm{~K} 27^{\circ} 23.496 \mathrm{D} 14 \mathrm{~m}$ \\
\hline 5 & Balıkesir-Marmara-Gündoğdu & $40^{\circ} 34.962 \mathrm{~K} 27^{\circ} 35.779 \mathrm{D} 61 \mathrm{~m}$ \\
\hline 6 & Balıkesir-Marmara-Gündoğdu & $40^{\circ} 35.002 \mathrm{~K} 27^{\circ} 35.853 \mathrm{D} 71 \mathrm{~m}$ \\
\hline 7 & Balıkesir-Marmara-Topağaç & $40^{\circ} 38.972 \mathrm{~K} 27^{\circ} 42.017 \mathrm{D} 28 \mathrm{~m}$ \\
\hline 8 & Balıkesir-Marmara-Viranköy & $40^{\circ} 39.420 \mathrm{~K} 27^{\circ} 36.161 \mathrm{D} 71 \mathrm{~m}$ \\
\hline 9 & Balıkesir-Marmara-Yanada & $40^{\circ} 38.792 \mathrm{~K} 27^{\circ} 42.250 \mathrm{D} 65 \mathrm{~m}$ \\
\hline 10 & Balıkesir-Marmara-Çınarlı & $40^{\circ} 37.460 \mathrm{~K} 27^{\circ} 31.975 \mathrm{D} 98 \mathrm{~m}$ \\
\hline
\end{tabular}

(S. fruticosa Mill.) türüne ait 10 popülasyonun tohumlarından elde edilen fideler kullanılmıștır. Çizelge 1.'de çalıșmada kullanılan Anadolu adaçayı (Salvia fruticosa Mill.) türüne ait tohumların toplandığı lokasyonlar görülmektedir.

Denemenin kurulduğu parselde Çizelge 2.'den görüldüğü üzere toprak orta bünyeli olup tuzluluk ve kireç sorunu yoktur. Toprak reaksiyonu bakımından hafif alkali olan deneme parselinin organik madde kapsamı düșük gözükmektedir. Parsel toprağı alınabilir fosfor ve değișebilir potasyum bakımından yeterli sınıfta yer almıștır.

Tekirdağ ilinde uzun yıllar ortalama sıcaklık $13.95{ }^{\circ} \mathrm{C}$, en yüksek ortalama sıcaklık 17.84 ${ }^{\circ} \mathrm{C}$ ve en düșük ortalama sıcaklık $10.24{ }^{\circ} \mathrm{C}$ olarak gerçekleșmiștir. Toplam yıllık yağıș miktarının ise yine uzun yıllar ortalaması göz önüne alındığında $576.80 \mathrm{~kg} / \mathrm{m}^{2}$ olduğu anlașılmaktadır (Anonim 2013).

Deneme, 2011 yllında tesadüf blokları deneme desenine göre 3 tekrarlamalı olarak Tekirdağ Bağcılık Araștırma İstasyonu deneme alanında kurulmuștur. Denemede dikim sıklığı $35 \times 20 \mathrm{~cm}$ olup, parsel boyu $6 \mathrm{~m}$, parsel eni

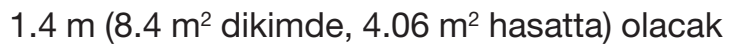
șekilde parselasyon yapılmıștır. Parseller arası mesafe $1.5 \mathrm{~m}$, bloklar arası mesafe $2 \mathrm{~m}$, her parselde 4 sira ve 124 bitki olacak șekilde hazırlanan deneme alanının toplam alanı 625 $\mathrm{m}^{2}$ olarak gerçekleșmiștir.

\section{Agronomik özelliklerin belirlenmesi}

\section{Yeșil herba verimi (kg/da)}

Her parselde, biçim yapıldıktan sonra elde edilen bitkilerin tartılması ve verilerin dekara çevrilmesi ile bulunmuștur.

\section{Kuru herba verimi ( $\mathrm{kg} / \mathrm{da})$}

Her parselde biçim yapıldıktan sonra elde edilen ürünün oda koșullarında kurutulup tartılması ve verilerin dekara çevrilmesi ile bulunmuștur.

\section{Yeșil yaprak verimi (kg/da)}

Yeșil herba ağırlığı bulunan bitkilerde yaprakların ayrılarak tartıması ve verilerin dekara çevrilmesi ile bulunmuștur.

Çizelge 2. Deneme alanındaki toprağın bazı fiziksel ve kimyasal özellikleri

Table 2. Some physical and chemical properties of soil in the experimental area

\begin{tabular}{cccccccc}
\hline $\begin{array}{c}\text { Derinlik } \\
(\mathrm{cm})\end{array}$ & $\begin{array}{c}\text { Tekstür } \\
(\%)\end{array}$ & $\begin{array}{c}\text { EC25 } \\
(1: 2.5) \\
(\mathrm{mmhos} / \mathrm{cm})\end{array}$ & $\begin{array}{c}\mathrm{pH} \\
(1: 2.5)\end{array}$ & $\begin{array}{c}\text { Kireç } \\
(\%)\end{array}$ & $\begin{array}{c}\text { Organik } \\
\text { Madde }(\%)\end{array}$ & $\begin{array}{c}\text { Alınabilir } \\
\text { Fosfor } \\
(\mathrm{ppm})\end{array}$ & $\begin{array}{c}\text { Değișebilir } \\
\text { Potasyum } \\
(\mathrm{ppm})\end{array}$ \\
\hline $0-30$ & 52 & 0.23 & 7.6 & 2.8 & 1.2 & 34 & 238 \\
& Killi tın & $\mathrm{Az}$ & $\begin{array}{c}\text { Hafif } \\
\text { Alkali }\end{array}$ & $\mathrm{Az}$ & $\mathrm{Az}$ & Yeterli & Yeterli \\
\hline
\end{tabular}


Çizelge 3. Tekirdağ iline ait 2011 ve 2012 yılı iklim verileri (Anonim 2013)

Table 3. Climate characteristics of Tekirdağ province in 2011 and 2012

\begin{tabular}{|c|c|c|c|c|c|c|c|c|c|c|}
\hline \multirow{3}{*}{$\begin{array}{l}\text { Yıllar } \\
\text { Aylar }\end{array}$} & \multicolumn{5}{|c|}{2011} & \multicolumn{5}{|c|}{2012} \\
\hline & \multicolumn{3}{|c|}{ Sıcaklıklar } & \multirow{2}{*}{$\begin{array}{c}\text { Ort. } \\
\text { Nem } \\
(\%)\end{array}$} & \multirow{2}{*}{$\begin{array}{l}\text { Yağıș } \\
\text { Top. } \\
(\mathrm{mm})\end{array}$} & \multicolumn{3}{|c|}{ Sıcaklıklar } & \multirow{2}{*}{$\begin{array}{c}\text { Ort. } \\
\text { Nem } \\
(\%)\end{array}$} & \multirow{2}{*}{$\begin{array}{l}\text { Yağıș } \\
\text { Top. } \\
\text { (mm) }\end{array}$} \\
\hline & Ort. & Max. & Min. & & & Ort. & Max. & Min. & & \\
\hline Ocak & 5.25 & 8.99 & 2.11 & 84.70 & 45.80 & 3.50 & 16.10 & -9.20 & 86.70 & 61.60 \\
\hline Șubat & 5.12 & 8.61 & 1.98 & 77.10 & 40.20 & 3.20 & 19.60 & -9.90 & 90.00 & 47.50 \\
\hline Mart & 7.13 & 10.70 & 3.98 & 79.40 & 25.20 & 7.90 & 21.60 & -2.50 & 81.80 & 22.70 \\
\hline Nisan & 10.40 & 14.02 & 6.89 & 76.10 & 75.20 & 14.10 & 25.00 & 1.90 & 82.40 & 70.00 \\
\hline Mayıs & 16.55 & 20.62 & 12.57 & 77.40 & 41.80 & 18.10 & 28.10 & 12.10 & 91.20 & 60.20 \\
\hline Haziran & 21.95 & 26.57 & 17.23 & 70.40 & 95.40 & 24.10 & 33.50 & 15.00 & 78.20 & 0.00 \\
\hline Temmuz & 25.52 & 30.07 & 20.53 & 67.50 & 7.80 & 27.00 & 35.80 & 18.60 & 69.00 & 5.50 \\
\hline Ağustos & 24.34 & 29.32 & 19.45 & 64.50 & 14.80 & 26.00 & 35.70 & 16.20 & 63.00 & 7.80 \\
\hline Eylül & 22.32 & 26.93 & 17.56 & 66.80 & 13.80 & 22.20 & 29.90 & 13.60 & 73.60 & 12.10 \\
\hline Ekim & 14.04 & 17.87 & 10.46 & 82.40 & 158.00 & 14.00 & 27.50 & 2.70 & 82.40 & 154.30 \\
\hline Kasım & 8.53 & 12.52 & 5.33 & 90.70 & 4.40 & 13.70 & 23.50 & 4.50 & 97.00 & 14.00 \\
\hline Aralık & 8.15 & 12.26 & 4.56 & 94.60 & 84.00 & 6.40 & 18.50 & -4.20 & 97.30 & 199.50 \\
\hline Ortalama & 14.10 & 18.20 & 10.22 & 77.63 & & 15.01 & 26.23 & 4.90 & 82.71 & \\
\hline
\end{tabular}

\section{Kuru yaprak verimi (kg/da)}

Oda koșullarında kurutulan yaprakların tartılması ve verilerin dekara çevrilmesi ile saptanmıștır.

\section{Kalite özelliklerinin belirlenmesi \\ Uçucu yağ oranı (\%)}

Her parselden elde edilen kuru yaprak örneklerinde uçucu yağ oranları Clevenger apareyi ile volümetrik olarak belirlenmiștir.

\section{Uçucu yağın bileșimi (\%)}

Uçucu yağlarda bulunan kimyasal bileșenlerin adları ve uçucu yağdaki oranları $\mathrm{GC}$ ve $\mathrm{GC} / \mathrm{MS}$ ile belirlenmiștir.

\section{Gaz kromatografisi (GC) analiz koșulları}

Sistem: Agilent 6890N GC GC analiz koșulları eș zamanlı olarak GC/MS sistemindeki madde çıkıș zamanları ile aynı olacak șekilde ayarlanmıștır (FID $300^{\circ} \mathrm{C}$ ). Bu amaçla kapiler kolon (HP Innowax Capillary; 60.0 m x 0.25 mm x $0.25 \mu \mathrm{m})$ kullanılmıștır. Öncelikle uçucu yağ örnekleri analiz edilmek üzere 1:50 oranında hekzan ile seyreltme ișlemine tabi tutulmuștur.

Gaz kromatografisi/kütle spektrometrisi (GC/MS) analiz koșulları

Sistem: Agilent 5975 GC-MSD sistemi Kolon: HP-Innowax Silika kapiler (60 m x 0.25 mm $\varnothing, 0.25$ m film kalınlığı) Sıcaklık Programı: $60^{\circ} \mathrm{C}$ de 10 dak $/ 4^{\circ} \mathrm{C} /$ dak artıșla $220^{\circ} \mathrm{C}$ ye//220 ${ }^{\circ} \mathrm{C}$ de 10 dak $/ / 1^{\circ} \mathrm{C} /$ dak artıșla $240^{\circ} \mathrm{C}$ ye Enjektör: $250^{\circ} \mathrm{C}$ Tașıyıcı Gaz: Helyum (0.8 $\mathrm{ml} /$ dak) Split oranı: Splitless Elektron enerjisi: 70 eV Kütle Aralığı: m/z 35-450 olacak șekilde cihaz șartlandırılmıștır.

Örneklerin uçucu yağın bileșenlerinin teșhisinde Bașer Uçucu Yağ Bileșenleri Kütüphanesi, Wiley ve Adams-LIBR (TP) Kütüphane Tarama Yazılımları kullanılmıștır. Elde edilen bileșenlerin yüzdeleri FID dedektör kullanılarak, tanımlaması ise MS dedektör kullanılarak yapılmıștır. Uçucu yağ bileșenlerinin alıkonma indisleri (RI), her bir bileșenin alıkonma zamanı ve C8-C22 karbon serili n-alkan serisinin aynı analiz koșulları için belirlenen alıkonma zamanları dikkate alınarak hesaplanmıștır.

Tarla denemesinden elde edilen verilerin istatistiki analizleri tesadüf blokları deneme desenine göre, JUMP 7.0 İstatistik Analiz Programı'nda yapılmıștır. Varyans analiz tablosunda önemli bulunan değerler LSD testine tabi tutularak incelenen karakterler açısından popülasyonlara ait ortalamalar birbirleri ile karșılaștırılmıștır. 


\section{Bulgular ve Tartıșma}

\section{Yeșil herba}

2011 yılı yeșil herba verimi ortalama değerleri incelendiğinde en yüksek verimin 4533.73 kg/ da ile 8 nolu popülasyondan, en düșük verimin ise $2743.47 \mathrm{~kg} / \mathrm{da}$ ile 10 nolu popülasyondan elde edildiği ve popülasyonlar ortalamasının 3506.67 kg/da olduğu görülmektedir. 2012 yılı toplam yeșil herba verimine baktığımız zaman 2011 yılında olduğu gibi 8 nolu popülasyonun en yüksek verim değerine (8093.48 kg/da) ulaștığını görmekteyiz. Yine 10 nolu popülasyon $3354.25 \mathrm{~kg} /$ da yeșil herba verimiyle en son sırada yer almaktadır. 2012 yılı toplam yeșil herba verim ortalaması ise $5181.70 \mathrm{~kg} /$ da olarak gerçekleșmiș ve 2011 yılı verim değerinden (3506.67 kg/da) daha yüksek olmuștur. Bayram ve ark. (1999), Bornova ekolojik koșullarında Anadolu adaçayı (Salvia fruticosa Mill.) ile yaptıkları çalıșmada, yeșil herba veriminin 1. yıl 1028.80-2055.57 kg/da, 2. yıl 2870.30-6558.60 kg/da arasında değișim gösterdiğini bildirmișler, Bayram (2001) ise aynı ekolojik koșullarda Anadolu adaçayı (Salvia fruticosa Mill.) klonlarında yeșil herba veriminin $639 \mathrm{~kg} / \mathrm{da}$ olduğunu belirtmiștir. Mossi et al. (2011), Brezilya ekolojik koșullarında yürüttüğü çalıșmada, Anadolu adaçayı (Salvia fruticosa Mill.) için yeșil herba verimini 1174 kg/da olarak belirlemișlerdir. Çalıșmamızdan elde edilen ortalama yeșil herba verim değerlerin
(1. yıl 3506.67 ve 2. yıl $5181.70 \mathrm{~kg} / \mathrm{da}$ ) yukarıda özetlenen çalıșmalardan elde edilen verim değerlerinden daha yüksek olmuștur.

\section{Kuru herba}

2011 yılında ortalama kuru herba verimi $1068.20 \mathrm{~kg} / \mathrm{da}$ olarak gerçekleșmiș, bu dönemde en yüksek verim 1494.86 kg/da ile 3 nolu, en düșük verim ise $862.84 \mathrm{~kg} / \mathrm{da}$ ile 10 nolu popülasyondan alınmıștır. 2012 yılı toplam kuru herba verimine baktığımız zaman 8 nolu popülasyonunun 2209.58 kg/da ile en yüksek, 10 nolu popülasyonun 1082.74 kg/da ile en düșük verime sahip olduğunu, 2012 yılı kuru herba verim toplamı ortalamasının $1537.96 \mathrm{~kg} /$ da olarak elde edildiğini görmekteyiz. 2012 yılı ortalama kuru herba verimi 2011 yılı veriminden biraz daha yüksektir. Ceylan ve Kaya (1989) Bornova ekolojik koșullarında Anadolu adaçayı (Salvia fruticosa Mill.) ile yürüttüğü çalıșmada kuru herba verimini ilk yıl $844 \mathrm{~kg} / \mathrm{da}, 2$. yıl $889 \mathrm{~kg} /$ da olarak belirlemiștir. Bayram ve ark. (1999) Bornova ekolojik koșullarında Anadolu adaçayı (Salvia fruticosa Mill.) üzerinde yürüttükleri çalıșmada kuru herba veriminin 1. yıl 475.40-871.00 kg/da, 2. yıl 666.67-2058.73 kg/da arasında değiștiğini saptamıșlardır. Bayram (2001) Bornova ekolojik koșullarında Anadolu adaçayı (Salvia fruticosa Mill.) ile yaptığı çalıșmada kuru herba verimini 258.1 kg/da olarak belirlemiștir.

Çizelge 4. Anadolu adaçayı (Salvia fruticosa Mill.)'da 2011 ve 2012 yılı hasatları yeșil herba verim (kg/da) değerleri

Table 4. Fresh herb yield (kg/da) of Anatolian sage (Salvia fruticosa Mill.) harvested in 2011 and 2012

\begin{tabular}{lll}
\hline Popülasyonlar & 2011 & 2012 \\
\hline 1 & $3039.62 \mathrm{bc}$ & $4737.74 \mathrm{~d}$ \\
2 & $3781.24 \mathrm{abc}$ & $6034.03 \mathrm{c}$ \\
3 & $4424.37 \mathrm{ab}$ & $5941.45 \mathrm{c}$ \\
4 & $3134.38 \mathrm{abc}$ & $4916.73 \mathrm{~d}$ \\
5 & $3187.08 \mathrm{abc}$ & $4316.36 \mathrm{e}$ \\
6 & $4527.58 \mathrm{a}$ & $3528.38 \mathrm{f}$ \\
7 & $4380.62 \mathrm{ab}$ & $6697.86 \mathrm{~b}$ \\
8 & $4533.73 \mathrm{a}$ & $8093.48 \mathrm{a}$ \\
9 & $3199.36 \mathrm{abc}$ & $4724.75 \mathrm{~d}$ \\
10 & $2743.47 \mathrm{c}$ & $3354.25 \mathrm{f}$ \\
Ort. & 3506.67 & 5181.70 \\
\hline CV (\%) & 23.59 & 3.06 \\
LSD (\%5) & 1419.46 & 272.02 \\
\hline
\end{tabular}


Çizelge 5. Anadolu adaçayı (Salvia fruticosa Mill.)'da 2011 ve 2012 yılı hasatlarına ait kuru herba verim (kg/da) değerleri

Table 5. Dry herb yield (kg/da) of Anatolian sage (Salvia fruticosa Mill.) harvested in 2011 and 2012

\begin{tabular}{lll}
\hline Popülasyonlar & 2011 & 2012 \\
\hline 1 & $939.53 \mathrm{~cd}$ & $1452.63 \mathrm{c}$ \\
2 & $1203.32 \mathrm{a}-\mathrm{d}$ & $1754.96 \mathrm{~b}$ \\
3 & $1494.86 \mathrm{a}$ & $1735.38 \mathrm{~b}$ \\
4 & $942.20 \mathrm{~cd}$ & $1524.85 \mathrm{c}$ \\
5 & $986.32 \mathrm{bcd}$ & $1399.63 \mathrm{c}$ \\
6 & $1390.82 \mathrm{ab}$ & $1163.45 \mathrm{~d}$ \\
7 & $1361.45 \mathrm{abc}$ & $1868.35 \mathrm{~b}$ \\
8 & $1370.74 \mathrm{ab}$ & $2209.58 \mathrm{a}$ \\
9 & $1013.12 \mathrm{bcd}$ & $1534.24 \mathrm{c}$ \\
10 & $862.84 \mathrm{~d}$ & $1082.74 \mathrm{~d}$ \\
Ort. & 1068.20 & 1537.96 \\
\hline CV (\%) & 23.27 & 6.64 \\
LSD (\%5) & 426.44 & 175.18 \\
\hline
\end{tabular}

\section{Yeșil yaprak}

2011 yılı yeșil yaprak verimlerine baktığımız zaman 3 nolu popülasyonun $2306.16 \mathrm{~kg} / \mathrm{da}$ ile en yüksek, 1 nolu popülasyonun $1371.50 \mathrm{~kg} /$ da ile en düșük verim grubunu olușturduğunu ve bu dönemde ortalama yeșil yaprak veriminin 1683.67 kg/da olduğunu görmekteyiz. 2012 yllı toplam yeșil yaprak veriminde de 1 . ve 2. hasatlarda olduğu gibi 8 nolu popülasyon $3782.03 \mathrm{~kg} / \mathrm{da}$ ile en yüksek verim grubunda, 10 nolu popülasyon $1703.36 \mathrm{~kg} / \mathrm{da}$ ile en düșük verim grubunda yer almıștır. 2012 yılı toplam yeșil herba verimi ortalamasına baktığımız zaman 2431.07 kg/da olarak gerçekleștiği anlașılmaktadır.

\section{Kuru yaprak}

2011 yılında 3 nolu popülasyon $691.62 \mathrm{~kg} /$ da ile en yüksek kuru yaprak verim değerine ulașmıș, 10 nolu popülasyon $439.86 \mathrm{~kg} /$ da ile en düșük verim grubunda yer almıștır. 2011 yılı kuru yaprak verimi popülasyon ortalaması $533.63 \mathrm{~kg} / \mathrm{da}$ olmuștur. 2012 yılı toplam kuru yaprak verim değerlerini incelediğimizde $330.96 \mathrm{~kg} / \mathrm{da}$ ile 8 nolu

Çizelge 6. Anadolu adaçayı (Salvia fruticosa Mill.)'da 2011 ve 2012 yılı hasatlarına ait yeșil yaprak verim (kg/da) değerleri

Table 6. Fresh foliage yield (kg/da) of Anatolian sage (Salvia fruticosa Mill.) harvested in 2011 and 2012

\begin{tabular}{lll}
\hline Popülasyonlar & 2011 & 2012 \\
\hline 1 & $1371.50 \mathrm{~d}$ & $2206.36 \mathrm{de}$ \\
2 & $1991.47 \mathrm{a}-\mathrm{d}$ & $2185.70 \mathrm{de}$ \\
3 & $2306.16 \mathrm{a}$ & $2831.70 \mathrm{c}$ \\
4 & $1461.54 \mathrm{~cd}$ & $2376.03 \mathrm{~d}$ \\
5 & $1595.83 \mathrm{bcd}$ & $1930.70 \mathrm{ef}$ \\
6 & $2170.78 \mathrm{ab}$ & $1760.03 \mathrm{f}$ \\
7 & $2286.63 \mathrm{a}$ & $3163.36 \mathrm{~b}$ \\
8 & $2060.48 \mathrm{abc}$ & $3782.03 \mathrm{a}$ \\
9 & $1679.58 \mathrm{a}-\mathrm{d}$ & $2371.70 \mathrm{~d}$ \\
10 & $1460.46 \mathrm{~cd}$ & $1703.36 \mathrm{f}$ \\
Ort. & 1683.67 & 2431.07 \\
\hline CV (\%) & 23.05 & 7.63 \\
LSD (\%5) & 665.97 & 318.54 \\
\hline
\end{tabular}


Çizelge 7. Anadolu adaçayı (Salvia fruticosa Mill.)'da 2011 ve 2012 yılı hasatlarına ait kuru yaprak verim (kg/da) değerleri

Table 7. Dry foliage yield (kg/da) of Anatolian sage (Salvia fruticosa Mill.) harvested in 2011 and 2012

\begin{tabular}{lll}
\hline Popülasyonlar & 2011 hasadı & 2012 hasadı \\
\hline 1 & $496.33 \mathrm{bc}$ & $601.76 \mathrm{f}$ \\
2 & $606.28 \mathrm{ab}$ & $703.32 \mathrm{~d}$ \\
3 & $691.62 \mathrm{a}$ & $771.52 \mathrm{c}$ \\
4 & $450.08 \mathrm{c}$ & $666.84 \mathrm{de}$ \\
5 & $462.35 \mathrm{bc}$ & $618.36 \mathrm{ef}$ \\
6 & $683.45 \mathrm{a}$ & $513.03 \mathrm{~g}$ \\
7 & $661.08 \mathrm{a}$ & $856.12 \mathrm{~b}$ \\
8 & $611.64 \mathrm{ab}$ & $986.70 \mathrm{a}$ \\
9 & $490.22 \mathrm{bc}$ & $619.45 \mathrm{ef}$ \\
10 & $439.86 \mathrm{c}$ & $507.74 \mathrm{~g}$ \\
Ort. & 533.63 & 672.70 \\
\hline CV (\%) & 16.69 & 5.64 \\
LSD (\%5) & 152.82 & 65.14 \\
\hline
\end{tabular}

popülasyonun en yüksek verim grubunda yer aldığını, 10 nolu popülasyonun ise $167.74 \mathrm{~kg} /$ da ile en son grupta yer aldığını görmekteyiz. 2012 yllı kuru yaprak verimi popülasyonlar arasındaki gruplandırmaya baktığımızda 8 nolu popülasyon $986.70 \mathrm{~kg} / \mathrm{da}$ verim değeri ile ilk grupta, 10 nolu popülasyon ise $507.74 \mathrm{~kg} /$ da ile en son grupta yer almaktadır. 2012 yılı kuru yaprak verimi popülasyonlar ortalaması $672.70 \mathrm{~kg} / \mathrm{da}$ olarak gerçekleșmiștir. Bayram (2001) Anadolu adaçayı (Salvia fruticosa Mill.) ile Bornova ekolojik koșullarında yaptığı çalıșmasında $161.3 \mathrm{~kg} /$ da kuru yaprak verimi elde etmiștir. Bizim çalıșmamızda her iki yılda elde ettiğimiz kuru yaprak verim değerlerinin belirtilen çalıșmadan elde edilen verim değerinden yüksek olduğu anlașılmaktadır.

\section{Uçucu yağ oranı}

2011 yılı hasadında en düșük uçucu yağ oranı \%3.26, en yüksek uçucu yağ oranı ise \%4.34 olarak gerçekleșmiș ve bu dönemde popülasyonlar ortalaması \%3.71 olmuștur. 2012 yılı 1. hasat döneminde uçucu yağ oranı popülasyonlar ortalaması $\% 3.03$ olarak gerçekleșmiș ve \%2.53 ile \%3.72 arasında değișmiștir. 2012 yılı 2. hasat dönemine baktığımızda ise popülasyonlar arasında uçucu yağ oranı açısından \%1 düzeyinde önemli farklılığın oluștuğunu görmekteyiz. En yüksek uçucu yağ oranı \%3.88 ile 5 nolu popülasyondan, en düșük uçucu yağ oranı ise
\%2.54 ile 1 nolu popülasyondan elde edilmiștir. Diğer bütün popülasyonların uçucu yağ oranı \%3'ün üzerinde bulunmuștur. Bu dönemde uçucu yağ oranı popülasyonlar ortalaması ise \%3.52 olarak gerçekleșmiștir.

Değișik ekolojilerde farklı araștııııılar tarafından yapılan çalıșmalar incelendiğinde Anadolu adaçayı (Salvia fruticosa Mill.)'nda uçucu yağ oranını; Putievsky ve ark. (1986) İsrail'de yürüttüğü çalıșmada \%1.4-3.8, Bayrak ve Akgül (1987) \%2.8, Ceylan ve Kaya (1988) Bornova ekolojik koșullarında \%2.33.5, Baydar ve ark. (1999) \%1.95, Bayram (2001) \%3.68, Naser et al. (2004) \%0.7-0.34, Bașer ve Kırımer (2006) \%0.9-2.8 arasında, Kocabaș ve ark. (2007) \%2.9, Karık ve Öztürk (2009) \%1.5, Așkun ve ark. (2010) \%2.3, Mossi et al. (2011) \%0.98 olarak bulmușlardır. Bizim yaptığımız çalıșmadan elde ettiğimiz uçucu yağ oranlarını bu çalıșmalar ile kıyasladığımızda yüksek değerler elde ettiğimiz görülmektedir.

Kalafatcılar (1996), Bornova ekolojik koșullarında yürüttüğü çalıșmasında, Salvia fruticosa Mill.'da uçucu yağ oranını \%1.5-5.15, Karousou and Kokkini (1997) Girit Adasından topladıkları Salvia fruticosa Mill. örneklerinde uçucu yağ oranını \%1-5.5, Bayram (1999) Bornova ekolojik koșullarında yürüttüğü çalıșmada uçucu yağ oranını \%1.03-5.40, Çiçek ve ark. (2011) Menemen ekolojik koșullarında yürüttükleri çalıșmada \%1.14-4.58 arasında 
Çizelge 8. Anadolu adaçayı (Salvia fruticosa Mill.)'da 2011 ve 2012 yılı hasatlarına ait uçucu yağ oranı (\%) değerleri

Table 8. Essential oil yield (\%) of Anatolian sage (Salvia fruticosa Mill.) harvested in 2011 and 2012

\begin{tabular}{llll}
\hline Popülasyonlar & 2011 hasadı & 20121. hasat & 2012 2. hasat \\
\hline 1 & 4.02 & 2.53 & $2.54 \mathrm{~d}$ \\
2 & 3.62 & 3.72 & $3.54 \mathrm{abc}$ \\
3 & 4.34 & 2.68 & $3.64 \mathrm{abc}$ \\
4 & 3.47 & 3.03 & $3.44 \mathrm{bc}$ \\
5 & 3.27 & 3.16 & $3.88 \mathrm{a}$ \\
6 & 4.08 & 3.13 & $3.61 \mathrm{abc}$ \\
7 & 3.26 & 2.86 & $3.81 \mathrm{ab}$ \\
8 & 4.04 & 3.17 & $3.68 \mathrm{abc}$ \\
9 & 3.35 & 3.08 & $3.44 \mathrm{bc}$ \\
10 & 3.28 & 2.93 & $3.38 \mathrm{c}$ \\
Ort. & 3.71 & 3.03 & 3.52 \\
\hline CV (\%) & & & 6.96 \\
LSD (\%5) & & & 0.42 \\
\hline
\end{tabular}

bulmușlardır. Bu çalıșmalarda bazı örneklerden elde ettikleri uçucu yağ oranı değerlerinin bizim çalıșmamızdan elde ettiğimiz değerlerden biraz yüksek olduğu görülmektedir. Bunun nedeni olarak çalıșmada kullanılan bitkisel materyalin toplandığı ekolojinin ve buna bağlı olarak bitkilerin genotipinin farklı olmasını, kültürü yapılan alanlardaki ekolojik farklı̆ı ve uygulanan kültürel ișlemler ile hasat veya toplama zamanlarının farklı olmasını söyleyebiliriz.

\section{Uçucu yağ bileșenleri}

Kültüre alınan Anadolu adaçayı (Salvia fruticosa Mill.) bitkisinde 2011 verim yllına ait uçucu yağların içermiș oldukları bileșenler Çizelge 9.'da görülmektedir. Uçucu yağlarda toplam 19 tane bileșenin tanımlandığı ve uçucu yağların yaklașık \%95'lik kısmının aydınlatıldığı görülmektedir. Salvia fruticosa Mill. uçucu yağında ana bileșenlerin 1.8-cineole ve camphor olduğu, bu bileșenlerin oranlarının örneklere göre değișim gösterdiği anlașılmaktadır. Uçucu yağlardaki 1.8-cineole oranı \%24.5-35.8 arasında değișmekle beraber, genelde \%30 civarında olduğunu söylemek mümkündür. Diğer önemli bileșen olan camphor incelendiğinde uçucu yağdaki oranının \%16.7-26.5 arasında değișim gösterdiği anlașılmaktadır. Bunların dıșında kalan bileșenlerden $\alpha$-pinene \%4.4-5.5, camphene \%4.9-6.9, $\beta$-pinene 6.1-7.3, $\beta$-caryophyllene \%4.7-6.7 arasında değișim göstermiș ve ana bileșenler olan 1.8-cineole ve camphor'dan sonra uçucu yağlarda oran olarak en fazla bulunan bileșenler olmuștur.

2012 verim yılı 1. hasat dönemine ait uçucu yağlarda toplam 18 adet bileșen tanımlanmıș ve uçucu yağların yaklașık \%95'i tanımlanmıștır (Çizelge 10). Bu dönemde hasat edilen bitkilerdeki uçucu yağların ana bileșenlerinin 1.8-cineole, camphor ve $\beta$-caryophyllene olduğu görülmektedir. Bu dönemde 2011 yılından farklı olarak $\beta$-caryophyllene'in de ana bileșenlerden olduğu göze çarpmaktadır. $\beta$-caryophyllene doğadan toplanan örneklerde de ana bileșenler arasında yer almaktadır. Anadolu adaçayı (Salvia fruticosa Mill.) uçucu yağının ana bileșenlerinden olan 1.8-cineole oranının \%25.9-37.3 arasında değișim gösterdiği anlașılmaktadır. Diğer ana bileșenlerden olan camphor oranı \%8.1$18.5, \beta$-caryophyllene oranı ise $\% 7.1-14.8$ arasında değerler içermektedir. Bu dönemde popülasyonlara göre değișim göstermekle birlikte uçucu yağlarda $\alpha$-pinene \%3.1-5.2, camphene \%2.4-6.8, $\beta$-pinene \%7.7-8.7 ve myrcene \%5.4-7.3 arasında bulunmuș ve ana bileșenlerden sonra gelerek diğer bileșenlerden oransal olarak daha büyük paya sahip olmuștur.

Anadolu adaçayı (Salvia fruticosa Mill.) popülasyonlarının 2012 yılı 2. hasat dönemindeki uçucu yağlarına ait bileșenlerin 
Çizelge 9. Anadolu adaçayı (Salvia fruticosa Mill.) 2011 yılı hasatına ait uçucu yağ bileșenleri (\%)

Table 9. Essential oil components of Anatolian sage (Salvia fruticosa Mill.) harvested in 2011 (\%)

\begin{tabular}{|c|c|c|c|c|c|c|c|c|c|c|c|}
\hline $\mathrm{RRI}$ & Bileșen & 1 & 2 & 3 & 4 & 5 & 6 & 7 & 8 & 9 & 10 \\
\hline 1032 & $\alpha$-pinene & 5.3 & 5.4 & 5.5 & 5.1 & 4.4 & 4.9 & 4.6 & 4.8 & 4.8 & 4.9 \\
\hline 1076 & camphene & 6.1 & 6.2 & 6.3 & 6.6 & 5.1 & 6.7 & 4.9 & 5.5 & 6.9 & 5.8 \\
\hline 1118 & $\beta$-pinene & 6.7 & 7.2 & 7.3 & 6.7 & 6.3 & 6.4 & 7.2 & 6.9 & 6.1 & 7.2 \\
\hline 1174 & myrcene & 3.6 & 3.4 & 3.3 & 3.3 & 3.5 & 3.2 & 3.5 & 3.6 & 3.2 & 3.5 \\
\hline 1203 & limonene & 1.9 & 2.0 & 2.2 & 2.5 & 2.0 & 2.6 & 2.2 & 2.5 & 2.6 & 2.4 \\
\hline 1213 & 1.8-cineole & 30.9 & 33.7 & 32.9 & 28.9 & 33.2 & 24.6 & 35.8 & 30.8 & 24.5 & 31.0 \\
\hline 1437 & $\alpha$-thujone & 1.5 & 1.5 & 1.6 & 2.6 & 1.2 & 1.7 & 1.4 & 1.1 & 1.6 & 0.9 \\
\hline 1451 & $\beta$-thujone & 0.9 & 0.6 & 1.6 & 1.2 & 2.1 & 1.4 & 2.5 & 1.3 & 1.5 & 1.0 \\
\hline 1532 & camphor & 18.3 & 16.7 & 18.5 & 21.4 & 17.8 & 25.2 & 17.2 & 21.2 & 26.5 & 21.1 \\
\hline 1553 & linalool & 1.2 & 0.9 & 1.2 & 1.0 & 1.2 & 1.4 & 0.9 & 1.0 & 1.1 & 1.1 \\
\hline 1565 & linalyl acetate & 2.0 & 1.5 & 2.1 & 2.3 & 2.7 & 3.2 & 2.3 & 2.0 & 2.3 & 2.1 \\
\hline 1590 & bornyl acetate & 0.7 & 0.6 & 0.5 & 0.7 & 0.3 & 0.6 & 0.4 & 0.3 & 1.1 & 0.6 \\
\hline 1612 & $\beta$-caryophyllene & 6.4 & 5.6 & 4.7 & 5.1 & 6.2 & 6.7 & 4.8 & 5.8 & 6.2 & 5.9 \\
\hline 1687 & $\alpha$-humulene & 1.6 & 1.7 & 1.4 & 1.6 & 1.9 & 1.9 & 2.3 & 1.4 & 2.4 & 1.3 \\
\hline 1706 & $\alpha$-terpineol & 2.3 & 2.8 & 2.3 & 0.8 & 1.9 & 0.9 & 0.5 & 2.1 & 1.0 & 1.5 \\
\hline 1709 & $\alpha$-terpinyl acetate & 1.1 & 0.9 & 1.2 & 0.9 & 0.9 & 1.0 & 1.0 & 1.0 & 0.9 & 1.0 \\
\hline 1719 & borneol & 2.4 & 1.9 & 1.5 & 2.4 & 1.3 & 1.7 & 1.6 & 1.8 & 2.1 & 2.0 \\
\hline 2104 & viridiflorol & 1.1 & 1.5 & 1.2 & 1.1 & 1.2 & 0.8 & 1.5 & 0.9 & 0.8 & 1.0 \\
\hline 2676 & manool & 1.3 & 0.8 & 0.5 & 0.6 & 1.0 & 0.9 & 0.8 & 0.9 & 0.6 & 0.7 \\
\hline \multicolumn{2}{|c|}{ Toplam (\%) } & 95.3 & 94.9 & 95.8 & 94.8 & 94.2 & 95.8 & 95.4 & 94.9 & 96.2 & 95 \\
\hline
\end{tabular}

içerik analizi incelendiğinde toplam 21 ana bileșenlerin 2011 verim yllında olduğu bileșenin tanımlandığı ve tanımlanan bu gibi bu hasat döneminde de 1.8-cineole ve bileșenlerin uçucu yağların yaklașık \%97'sini camphor olduğu görülmektedir. Bunun bașlıca olușturduğu anlașılmaktadır. Uçucu yağlardaki nedeni 2011 yılında yapılan hasat ile 2012

Çizelge 10. Anadolu adaçayı (Salvia fruticosa Mill.) 2012 yılı 1. hasatına ait uçucu yağ bileșenleri (\%) Table 10. Essential oil components of Anatolian sage (Salvia fruticosa Mill.) harvested $1^{\text {st }}$ time in 2012 (\%)

\begin{tabular}{|c|c|c|c|c|c|c|c|c|c|c|c|}
\hline RRI & Bileșen & 1 & 2 & 3 & 4 & 5 & 6 & 7 & 8 & 9 & 10 \\
\hline 1032 & $\alpha$-pinene & 3.5 & 5.2 & 3.1 & 4.0 & 3.9 & 3.6 & 4.4 & 4.3 & 4.7 & 4.2 \\
\hline 1076 & camphene & 2.4 & 6.8 & 2.3 & 3.8 & 2.9 & 3.0 & 3.8 & 3.4 & 4.9 & 4.1 \\
\hline 1118 & $\beta$-pinene & 8.5 & 7.7 & 7.7 & 8.1 & 7.8 & 8.7 & 8.5 & 7.7 & 8.4 & 8.0 \\
\hline 1174 & myrcene & 7.0 & 5.4 & 6.4 & 6.4 & 6.2 & 5.7 & 7.3 & 6.7 & 6.1 & 6.3 \\
\hline 1203 & limonene & 1.4 & 1.5 & 1.2 & 1.2 & 0.7 & 1.4 & 1.5 & 0.5 & 1.4 & 1.7 \\
\hline 1213 & 1.8-cineole & 30.8 & 25.9 & 31.1 & 30.8 & 37.3 & 31.6 & 31.3 & 33.7 & 30.9 & 30.8 \\
\hline 1437 & $\alpha$-thujone & 1.4 & 0.9 & 1.0 & 1.3 & 0.6 & 1.9 & 0.3 & 0.4 & 1.7 & 1.1 \\
\hline 1451 & $\beta$-thujone & 1.0 & 0.4 & 1.2 & 1.2 & 1.5 & 1.7 & 0.5 & 1.3 & 1.0 & 1.1 \\
\hline 1532 & camphor & 10.3 & 18.5 & 12.2 & 12.9 & 8.1 & 10.5 & 11.2 & 12.7 & 12.6 & 15.2 \\
\hline 1590 & bornylacetate & 1.0 & 1.9 & 0.5 & 1.1 & 0.4 & 1.2 & 1.1 & 0.6 & 1.5 & 0.7 \\
\hline 1612 & $\beta$-caryophyllene & 13.0 & 7.1 & 14.8 & 13.2 & 14.6 & 14.5 & 13.0 & 13.8 & 11.3 & 11.1 \\
\hline 1628 & aromadendrene & 1.6 & 0.4 & 1.2 & 1.1 & 1.1 & 0.9 & 1.1 & 1.1 & 0.5 & 1.2 \\
\hline $\begin{array}{l}1682 \\
1687\end{array}$ & $\begin{array}{l}\text { d-terpineol } \\
\alpha \text {-humulene }\end{array}$ & 3.7 & 2.9 & 3.6 & 2.2 & 3.3 & 2.5 & 2.3 & 2.4 & 2.8 & 2.9 \\
\hline 1706 & $\alpha$-terpineol & 3.6 & 2.9 & 2.1 & 3.3 & 2.0 & 1.3 & 2.3 & 1.0 & 2.0 & 2.3 \\
\hline 1719 & borneol & 0.9 & 2.9 & 1.2 & 0.1 & 0.6 & 0.9 & 1.1 & 1.3 & 1.7 & 1.3 \\
\hline 2104 & viridiflorol & 3.0 & 3.2 & 2.8 & 1.6 & 1.7 & 1.5 & 2.0 & 1.4 & 1.3 & 2.1 \\
\hline 2676 & manool & 2.3 & 2.8 & 2.6 & 1.7 & 1.5 & 1.3 & 1.5 & 1.5 & 2.1 & 1.0 \\
\hline \multicolumn{2}{|c|}{ Toplam (\%) } & 95.4 & 96.4 & 95 & 94 & 94.2 & 92.2 & 93.2 & 93.8 & 94.9 & 95.1 \\
\hline
\end{tabular}


Çizelge 11. Anadolu adaçayı (Salvia fruticosa Mill.) 2012 yılı 2. hasatına ait uçucu yağ bileșenleri (\%)

Table 11. Essential oil components of Anatolian sage (Salvia fruticosa Mill.) harvested $2^{\text {nd }}$ time in 2012 (\%)

\begin{tabular}{|c|c|c|c|c|c|c|c|c|c|c|c|}
\hline RRI & Bileșen & 1 & 2 & 3 & 4 & 5 & 6 & 7 & 8 & 9 & 10 \\
\hline 1032 & $\alpha$-pinene & 6.2 & 4.7 & 5.1 & 4.9 & 4.4 & 5.3 & 4.4 & 4.8 & 6.2 & 5.1 \\
\hline 1076 & camphene & 7.6 & 3.9 & 6.6 & 6.4 & 5.3 & 7.9 & 4.2 & 4.8 & 8.7 & 7.1 \\
\hline 1118 & $\beta$-pinene & 7.3 & 7.6 & 6.4 & 6.5 & 6.6 & 6.4 & 6.5 & 7.2 & 6.8 & 6.0 \\
\hline 1174 & myrcene & 2.5 & 3.6 & 2.7 & 2.9 & 2.7 & 2.7 & 3.2 & 2.8 & 2.8 & 2.9 \\
\hline 1203 & limonene & 2.3 & 2.1 & 2.6 & 2.6 & 2.3 & 3.0 & 2.3 & 2.2 & 2.6 & 2.9 \\
\hline 1213 & 1.8-cineole & 30.9 & 37.3 & 29.4 & 28.9 & 33.5 & 23.2 & 37.3 & 36.3 & 26.7 & 27.6 \\
\hline 1437 & $\alpha$-thujone & 1.7 & 1.7 & 2.1 & 1.5 & 1.1 & 1.5 & 1.5 & 1.3 & 2.2 & 1.1 \\
\hline 1451 & $\beta$-thujone & 0.9 & 2.0 & 1.2 & 1.2 & 2.2 & 1.7 & 1.6 & 1.6 & 1.5 & 1.5 \\
\hline 1532 & camphor & 19.4 & 12.2 & 22.0 & 23.4 & 18.8 & 29.1 & 16.9 & 17.5 & 23.5 & 25.5 \\
\hline 1553 & linalool & 1.6 & 1.3 & 1.0 & 1.2 & 1.3 & 1.1 & 1.3 & 1.1 & 0.8 & 1.4 \\
\hline 1565 & linalylacetate & 2.1 & 2.6 & 2.6 & 2.4 & 3.7 & 2.8 & 3.3 & 2.6 & 1.3 & 2.1 \\
\hline 1590 & bornylacetate & 1.0 & 0.3 & 0.7 & 0.8 & 0.5 & 0.9 & 0.4 & 0.4 & 1.0 & 0.5 \\
\hline 1612 & $\beta$-caryophyllene & 2.8 & 6.6 & 4.7 & 4.5 & 4.8 & 4.4 & 5.5 & 4.8 & 3.7 & 4.0 \\
\hline $\begin{array}{l}1682 \\
1687\end{array}$ & $\begin{array}{l}\text { d-terpineol } \\
\alpha \text {-humulene }\end{array}$ & 1.8 & 2.2 & 1.9 & 1.6 & 2.2 & 1.5 & 2.2 & 2.2 & 1.9 & 1.7 \\
\hline $\begin{array}{l}1706 \\
1709\end{array}$ & $\begin{array}{l}\alpha \text {-terpineol } \\
\alpha \text {-terpinylacetate }\end{array}$ & 4.2 & 5.0 & 3.0 & 2.3 & 3.1 & 1.2 & 2.4 & 3.8 & 2.6 & 2.6 \\
\hline 1719 & borneol & 2.5 & 1.2 & 2.9 & 2.2 & 1.6 & 2.2 & 1.3 & 1.3 & 3.1 & 2.0 \\
\hline 2008 & caryophylleneoxide & 0.8 & 1.1 & 0.9 & 1.1 & 0.8 & 0.8 & 0.8 & 0.8 & 0.9 & 1.0 \\
\hline 2104 & viridiflorol & 0.8 & 1.2 & 0.8 & 1.0 & 1.0 & 0.7 & 1.2 & 0.8 & 0.6 & 0.9 \\
\hline 2676 & manool & 0.9 & 0.8 & 0.6 & 0.5 & 0.6 & 0.6 & 0.6 & 0.6 & 0.4 & 0.2 \\
\hline \multicolumn{2}{|c|}{ Toplam (\%) } & 97.3 & 97.4 & 97.2 & 95.9 & 96.5 & 97.0 & 96.9 & 96.9 & 97.3 & 96.1 \\
\hline
\end{tabular}

yılında yapılan 2. hasadın Eylül ayına denk gelmesi ile açıklanabilir. 2012 yılı 2. hasat döneminde uçucu yağlardaki 1.8-cineole oranı \%23.2-37.3 arasında değișim göstermektedir. Diğer ana bileșen olan camphor 2011 yılındaki örnekler ile benzerlik göstermekte ve \%12.2-29.1 arasında yer almaktadır. 2012 yılı 1. hasat döneminde uçucu yağların ana bileșenlerinden olan $\beta$-caryophyllene bu hasat döneminde oldukça düșük seviyelerde \%2.86.6 kalmıștır. Ana bileșenlerden sonra gelen ve diğer bileșenlere göre oranı nisbeten fazla olan $\alpha$-pinene \%4.4-6.2, camphene \%3.98.7 ve $\beta$-pinene \%6.0-7.6 arasında değerler içermektedir (Çizelge 11.).

Ceylan ve Kaya (1988), Bodrum yöresinden topladıkları Salvia fruticosa Mill. popülasyonları ile Bornova'da yürüttükleri çalıșmada, uçucu yağın ana bileșeninin 1.8-cineole olduğunu ve bunun oranının \%10.0-69.3 arasında değișim gösterdiğini saptamıșlardır. Kırımer ve ark. (1991) Salvia fruticosa Mill. uçucu yağında ana bileșen olarak \%62 oranında 1.8-cineole bulduklarını belirtmișlerdir. Baydar ve ark. (1999) Isparta yöresinden topladığı
Salvia fruticosa Mill. örneklerinde uçucu yağın ana bileșeni olarak \%19.57 oranında 1.8-cineole bulmușlardır. Skoula et al. (2000) Girit adasından topladığı Salvia fruticosa Mill. popülasyonlarında uçucu yağın ana bileșeninin 1.8-cineole olduğunu ve oranının \%48.0659.27 arasında değiștiğini belirtmektedirler. Karioti et al. (2003) ve Naser et al. (2004) Salvia fruticosa Mill. bitkisi ile yaptıkları çalıșmada uçucu yağlarda ana bileșen olarak 1.8-cineole'ü bulmușlardır. Bașer ve Kırımer (2006) Türkiye'de yetișen Salvia fruticosa Mill. bitkilerinde yaptıkları kapsamlı çalıșmada uçucu yağın ana bileșenlerinin 1.8-cineole ve camphor olduğunu ve oranlarının sırası ile \%35-51 ve \%7-13 arasında değiștiğini bildirmișlerdir. Așkun ve ark. (2010), Kocabaș ve ark. (2010) ve Karık (2015) Salvia fruticosa Mill. ile yaptıkları çalıșmada uçucu yağda ana bileșenin 1.8-cineole, oranının ise sırasıyla \%52.8, \%50.7 ve \%46.9 olduğunu belirlemișlerdir. Ülkemizde ve dünyada yapılan çalıșmalar incelendiğinde, Salvia fruticosa Mill. uçucu yağının ana bileșeninin 1.8-cineole olduğu görülmektedir. Bizim yaptığımız 
çalıșmada da her iki hasat yılında bütün popülasyonların uçucu yağında ana bileșen olarak 1.8-cineole bulunmuștur.

\section{Sonuç}

Marmara Bölgesi'ndeki Anadolu adaçayı (Salvia fruticosa Mill.) popülasyonlarının verim ve kalite özelliklerinin belirlenmesi amacı ile yürütülen bu çalıșmadan, aynı tür ile yapılan diğer çalıșmalarla kıyaslandığında verim ve kalite değerleri açısından oldukça tatmin edici sonuçlar alınmıștır. 2011 yılı yeșil herba verimi popülasyonlar ortalamasının $3506.67 \mathrm{~kg} / \mathrm{da}$, 2012 yilı yeșil herba verim ortalamasının ise $5181.70 \mathrm{~kg} / \mathrm{da}$ olduğu görülmektedir. 2011 yllında ortalama kuru herba verimi 1068.20 kg/ da, 2012 yll kuru herba verim toplamı ortalaması 1537.96 kg/da olarak gerçekleșmiștir. 2011 yılı ortalama yeșil yaprak veriminin $1638.67 \mathrm{~kg} /$ da, 2012 yllı yeșil yaprak verimi ortalamasının $2431.07 \mathrm{~kg} / \mathrm{da}$ olarak gerçekleștiği anlașılmaktadır. 2011 ylı kuru yaprak verimi popülasyonlar ortalaması $533.63 \mathrm{~kg} / \mathrm{da}, 2012$ yılı kuru yaprak verimi popülasyonlar ortalaması 672.70 kg/da olarak gerçekleșmiștir. 2011 yılı hasadında en düșük uçucu yağ oranı \%3.26, en yüksek uçucu yağ oranı ise \%4.34 olarak gerçekleșmiș ve bu dönemde popülasyonlar ortalaması \%3.71 olmuștur. 2012 yılı 1. hasat döneminde uçucu yağ oranı popülasyonlar ortalaması \%3.03 olarak gerçekleșmiș ve \%2.53 ile \%3.72 arasında değișmiștir. 2012 yılı 2. hasat döneminde uçucu yağ oranı \%3.88 ile \%2.54 arasında ölçülürken, bu dönemde uçucu yağ oranı popülasyonlar ortalaması \%3.52 olarak gerçekleșmiștir. Ülkemizde ve dünyada Anadolu adaçayı (Salvia fruticosa Mill.) uçucu yağı ile ilgili yapılan çalıșmalarda ana bileșenin 1.8-cineole olduğu bilinmektedir. Yürüttüğümüz çalıșmada, uçucu yağlardaki 1.8-cineole oranı \%23.2-37.3, camphor oranı \%8.1-29.1, $\alpha$-pinene \%3.1-6.2, camphene \%2.3-8.7, $\beta$-pinene $\% 6.0-8.7$ ve $\beta$-caryophyllene $\% 2.8-$ 14.8 arasında değișmiștir.

Anadolu adaçayı, Marmara Bölgesinde Tekirdağ civarı ve Marmara Adasından toplanmaktadır. Özellikle Tekirdağ civarında dağılım gösterdiği yerlere yapılan sörveylerde, buradaki popülasyonların așırı toplamadan oldukça zarar gördüğü tespit edilmiștir.
Bitkilerde vejetatif gelișmenin neredeyse durduğu ve tamamen odunsulașarak çalı formuna dönüștüğü görülmüștür. Yine bu bölgede, bazı popülasyonların tamamen sökülerek meyve bahçesi haline getirildiği, üzerine kamp alanları ve turistik tesisler yapıldığı anlașılmıștır. Konu ile ilgili çevre köylerde gerekli uyarılar yapılarak konuya daha hassas yaklașmaları yönünde telkinlerde bulunulmuștur. Her iki verim yilında da kuru yaprak verimi açısından ön plana çıkan ve hastalıklara karșı fazla hassas olmadığı gözlemlenen uçucu yağ ve kuru yaprak verimi yüksek, uçucu yağında 1.8-cineole oranı yüksek, camphor oranı düșük olan popülasyonlar kullanılarak çalıșmanın bundan sonraki kısmında uygun ıslah yöntemi ile çeșit geliștirilmesi hedeflenmektedir. Sekiz nolu popülasyon verim değerleri açısından üstün ancak uçucu yağında fazla miktarda camphor tașıması nedeniyle popülasyon içinde yapılacak tek bitki gözlemleri ve kalite analizleri neticesine göre düșük camphor içeren bitkiler seçilerek değerlendirilebilecektir.

\section{Kaynaklar}

Anonim, 2012. TÜBiTAK -Türkiye Bitkileri Veri Servisi. http://www.tubitak.gov.tr

Anonim, 2013. Tekirdağ Meteoroloji Müdürlüğü 2011-2012 kayıtları

Așkun T., Bașer K.H.C., Tümen G., and Kürkçüoğlu M., 2010. Characterization of essential oils of some Salvia species and their antimycobacterial activities. Turkish Journal of Biology, 34:89-95

Baser K.H.C., and Kirimer N., 2006. Essential oils of Lamiaceae plants of Turkey. Acta Horticulture, 723:163-172

Baser K.H.C., 2002. Aromatic biodiversity among the flowering plant taxa of Turkey. Pure Applying Chemistry, 74(4):527-545

Baydar H., Marquard R.A. ve Karadoğan T., 1999. Isparta yöresinden toplanarak ihracat edilen bazı önemli Origanum, Coridothymus, Thymbra, Salvia L. türlerinin uçucu yağ verimi ve kompozisyonu. Türkiye 3. Tarla Bitkileri Kongresi 15-18 Kasım, Adana, Cilt II, Endüstri Bitkileri, s.416-420

Bayrak A., and Akgül A., 1987. Composition of essential oils from Turkish Salvia L. spp. Journal of Phytochemistry, 26(3):846-847

Bayram E., 2001. Batı Anadolu florasında yetișen Anadolu adaçayı (Salvia fruticosa Mill.)'nda uygun tiplerin seleksiyonu üzerinde araștırma. Turkish Journal of Agriculture and Forestry, 25:351-357 
Bayram E., Ceylan A. ve Geren H., 1999. Anadolu adaçayı (Salvia fruticosa Mill.) ıslahında geliștirilen klonların agronomik ve kalite özellikleri üzerinde araștırma. Türkiye 3. Tarla Bitkileri Kongresi, Cilt II, pp.212-217

Baytop T., 1999. Türkiye'de Bitkiler ile Tedavi Geçmiște ve Bugün. Nobel Tıp Kitabevleri Ltd. Ști. İstanbul, $550 \mathrm{~s}$

Ceylan A., 1997. Tıbbi Bitkiler II. Ege Üniversitesi Ziraat Fakültesi Yayınları, 481, 2. Baskı, $188 \mathrm{~s}$

Ceylan A., Kaya N. ve Çelik N., 1989. Anadolu adaçayı (Salvia triloba L.) üzerinde agronomik araștırmalar. Ege Üniversitesi Ziraat Fakültesi Dergisi, 25(3):167-184

Chalchat J.C., Michet A., and Pasquier B., 1998. Study of the clones of Salvia officinalis L. Yields and chemical composition of essential oil. Flavour and Fragrance Journal 13:68-70

Çiçek F., Tutar M., Sarı A.O. ve Bilgiç A., 2011. Anadolu adaçayı (Salvia fruticosa Mill.) yapraklarında uçucu yağ oranlarının aylara göre değișimi. Türkiye 9. Tarla Bitkileri Kongresi, 12-15 Eylül 2011 Bursa. Endüstri Bitkileri ve Biyoteknoloji, Cilt: 2, s.1287-1290

Davis P.H., 1982. Flora of Turkey and The East Aegean Island, Vol. 7. Edinburg University University Press, Edinburgh, pp.400-439

Demirci B., Bașer K.H.C., and Tumen G., 2002. Composition of the essential oil of Salvia aramiensis Rech. Fil. growing in Turkey. Journal of Flavour and Fragrance, 17:23-25

Güner A., Özhatay N., Ekim T., and Bașer K.H.C., 2000. Flora of Turkey and the East Aegean Islands. 11(Suppl 2):35-37. Edinburgh: Edinburgh University Press

Güner A., Aslan S., Ekim T., Vural M. ve Babaç M.T. (Edlr.), 2012. Türkiye Bitkileri Listesi (Damarlı Bitkiler). Flora Araștırmaları Derneği ve Nezahat Gökyiğit Botanik Bahçesi Yayını, İstanbul

Hedge I.C., and Salvia L., 1982. In: P. H. Davis (ed.) Flora of Turkey and the East Aegean Islands, Vol. 7, Edinburg University Press, Edinburg, pp. 400-461

İpek A. ve Gürbüz B., 2010. Türkiye florasında bulunan Salvia L. türleri ve tehlike durumları. Tarla Bitkileri Merkez Araștırma Enstitüsü Dergisi 19:30-35

Kalafatcılar Ö.A., 1996. Uçucu yağ bitkileri ekotiplerinin bazı morfolojik, anatomik ve kalite kriterleri üzerinde araștırma. Ege Üniversitesi, Fen Bilimleri Enstitüsü, Tarla Bitkileri Ana Bilim Dalı (doktora tezi, basılmamıș), $56 \mathrm{~s}$

Karık U. ve Öztürk M., 2010. Tıbbi ve aromatik bitkiler ile uçucu yağ sektörünün ülkemiz dıș ticaretindeki yeri ve önemi. 19. Bitkisel İlaç Hammaddeleri Toplantısı Mersin. Bildiri Kitabı s.182-197

Karık Ü., 2015. Some Yield and Quality Characteristics of Anatolian Sage (Salvia fruticosa Mill.) Populations in Aegean and West Mediterranean Region. Journal of Tekirdag Agricultural Faculty 12(2):32-42
Karioti A., Skaltsa H., Demetzos C., Perdetzoglou D., Economakis C.D., and Salem A.B., 2003. Effect of nitrogen concentration of the nutrient solution on the volatile constituents of leaves of Salvia fruticosa Mill. in solution culture. Journal of Agriculture Food Chemistry 51:6505-6508

Karoussou R., and Kokkini S., 1997. Distrubition and clinal varitian of Salvia fruticosa Mill. (Labiateae) on the Island of Crete (Greece). Willdenowia 27:113-117

Kırımer N., Cingi M.I., Öztürk N., Aydın S., Özkul H. ve Bașer K.H.C., 1991. Salvia sclarea, Salvia fruticosa Mill. ve Dorystoechas hastata uçucu yağlarının farmakolojik etkileri. 9. Bitkisel İlaç Hammaddeleri Toplantısı, 16-19 Mayıs 1991. Eskișehir. s.382-388

Kocabaș F.I., Kaplan M., Kürkçüoğlu M., and Bașer K.H.C., 2010. Effects of different organic manure applications on the essential oil components of Turkish sage (Salvia fruticosa Mill.). Asian Journal of Chemistry 22(2):1599-1605

Kocabaș I., Sönmez A.i.., Kalkan H. ve Kaplan M., 2007. Farklı organik gübrelerin adaçayı (Salvia fructicosa Mill.)'nın uçucu yağ oranı ve bitki besin maddeleri içeriğine etkileri. Akdeniz Üniversitesi Ziraat Fakültesi Dergisi 20(1):105-110

Lu Y., and Foo L.Y., 2002. Polyphenolics of Salvia L.- a review. Phytochemistry 59:117-140

Mossi A.J., Cansian R.L., Paroul N., Toniazzo G., Oliveira J.V., Pierozan M.K., Pauletti G., Rota L., Santos A.C., and Serafini L.A., 2011. Morphological characterisation and agronomical parameters of different species of Salvia L. sp. (Lamiaceae). Brazilian Journal of Biology 71(1):121-129

Nakiboğlu M., 2002. The Classification of the Salvia L. (Labiatae) Species Distributed in West Anatolia According to Phenolic Compounds. Turkish Journal of Botany 26:103-108

Nakipoğlu M., 1993. Türkiye'nin Bazı Salvia L. Türleri Üzerinde Karyolojik Araștırmalar I, S. fruticosa Mill., S. tomentosa Mill., S. smyrnaea Boiss. (Lamiaceae). Doğa Turkish Journal of Botany 17:21-25

Naser A., Arikat A., Fawzia M., Jawad B., Nabila S., Karama R.A., and Shibli A., 2004. Micropropagation and accumulation of essential oils in wild sage (Salvia fruticosa Mill.). Scientia Horticulturae 100:193-202

Perry N.S., Bollen C., Perry E.K., and Ballard C., 2003. Salvia L. for dementia therapy: review of pharmacological activity and pilot tolerability clinical trial. Pharmacology, Biochemistry and Behavior 75(3):651-659

Pignatti S., 1982. Flora d' Italia, Vol. 2, Edagricole, Bologna

Putievsky E., Ravid U., and Dudai N., 1986. The essential oil and yield components from various plant parts of Salvia fruticosa Mill. Journal of Natural Products 49:1015-1017 DOI: 10.1021/ np50048a008 
Rivera D., Obon C., and Cano F., 1994. The botany, history and traditional uses of three-lobed sage (Salvia fruticosa Mill.) (Labiateae). Economic Botany 48:190-195

Seçmen Ö., Gemici Y., Görk G., Bekat L. ve Leblebici E., 2000. Tohumlu Bitkiler Sistematiği. Ege Üniversitesi Fen Fakültesi Kitaplar Serisi No: 116. İzmir

Skoula M., 1994. Indigenous knowledge in the use plants in human health in Crete, Greece. In Proceedings of the International Seminar on Indigenous Knowledge on Adaptation and Development-Interdisciplinary Perspective on Subsistence and Sustainability in Developing Countries (Bandung, 11-15 July 1999), pp. 459468
Șenkal B.C., İpek A. ve Gürbüz B., 2012. Türkiye florasında bulunan adaçayı (Salvia L. spp.) türlerinin uçucu yağ içeriklerinin değerlendirilmesi. Tıbbı ve Aromatik Bitkiler Sempozyumu 13-15 Eylül 2012 Tokat. Bildiri Kitabı, s.166-176

Topçu G., 2006. Bioactive triterpenoids from Salvia L. species. Journal of Natural Products, 69(3):482-487

Ulubelen A., 1964. Cardioactive and antibacterial terpenoids from some Salvia L. species. Phytochemisry 64:395-399 